\title{
Thematic Mapping of COVID-19 Spread in Nigeria: A Tool for Pandemic Rapid Containment Measures
}

\author{
Adebayo.H. Oluwasegun \\ Department of Geography, Olabisi Onabanjo University, Ago-Iwoye, Ogun State, Nigeria \\ Email Address: adebayooluwasegunhezekiah@gmail.com; adebayo.oluwasegun@oouagoiwoye.edu.ng
}

\begin{abstract}
Since the end of 2019, pneumonia, later named 2019 novel corona virus disease (COVID-19), originated in Wuhan and rapidly spread throughout the globe including Nigeria. This study explored the techniques of Thematic mapping in assessing the spread of COVID-19 across the thirty-six states in Nigeria with the main objective of showing how thematic maps can be employed in explaining pandemic situations for easy interpretation and quick decisionmaking. The study relies on publicly available data on confirmed cases and death across Nigeria from the website of Nigeria Centre for Diseases Control (NCDC). Geo-visualization analysis technique was adopted for this study with results presented in form of maps. Results show that Lagos $(34.7 \%, 18.8 \%)$ Kaduna $(6.0 \%, 4.0 \%)$ Plateau $(5.5 \%, 3.4 \%)$ Oyo $(4.5 \%, 3.9 \%)$ Rivers $(3.9 \%, 4.9 \%)$ states and the Federal Capital Territory (FCT), Abuja $(13.4 \%, 7.9 \%)$ are hardly hit by COVID-19 in terms of the total number of both confirmed cases $(90,147)$ and deaths $(1,311)$ cases respectively as at Sunday 3th of January, 2021. The use of thematic maps for easy explanations, effective planning, preparedness and response to pandemic phenomena was equally established by this study. Since the virus spreads easily through human to human contact, it is recommended that restrictions of movements should be the priority of every concern stakeholder..
\end{abstract}

Keywords: Thematic Mapping, Geographic Information System, COVID-19, Spread, Containment

\section{Introduction}

The COVID-19 global pandemic has impacted the whole of society, requiring rapid implementation of individual-, population-, and system-level public health responses to contain and reduce the spread of infection. COVID-19 originated in Wuhan, China, with the first cases reported in December 2019 (WHO, 2020) and was officially declared as a public health emergency of international concern on January 30, 2020, by the World Health Organization. The first Nigerian confirmed case of COVID-19 was on February 28, 2020, in Lagos (NCDC, 2020), subsequently resulting in the closing of Nigerian borders to all non-residents in March. Physical distancing rules were imposed on March 30, 2020, with the associated closure of all non-essential services including retail outlets, cafés, restaurants, schools, recreational facilities, and playgrounds. To assist in physical distancing, additional measures including working, studying, or completing school from home were imposed; social gatherings were banned, and stringent restrictions on individual movement were put in place (NCDC, 2020). These public health policies profoundly impacted individual and population-level health, disrupted normal social interactions, and contributed to economic insecurity. Currently, the impact of COVID-19 on Nigerians and its associated levels of distress are poorly understood, yet are critical in ascertaining the spread by presenting it in a visual understanding. COVID-19 as an object of this study is a thematic polyhedron where geographical variables are present in several of its facets.
A thematic mapping is a type of mapping technique that portrays the geographic pattern of a particular subject matter (theme) in a geographic area (Dent et al., 2009; Robinson, 1982). Thematic Maps focus on a specific theme by pulling together relevant information of the subject (such as health, election, income, etc.) and represents it spatially to understand the relationship between these themes and their locations. Its usually involves the use of map symbols to visualize selected properties of geographic features that are not naturally visible (Kraak and Omeling, 2003; Bartz Petchenik, 1979; Keates, 1973). Thematic mapping is closely allied with the field of Geovisualization. Therefore, the aim of this study is to employ thematic mapping techniques in explaining the spread pattern of COVID-19 in Nigeria with the objective of using it as a tool for showing pictorially the direction of spread and a guide in taking quick and rapid decision for effective containment of the virus.

\subsection{Study Area}

Nigeria is situated between Latitudes $4^{\circ}$ and $14^{\circ}$ North of the Equator and Longitudes $3^{\circ}$ and $14^{\circ}$ East of Greenwich Meridian. The country is bordered on the west by the Republic of Benin; on the east by the Republic of Cameroon; on the north by Niger and Chad Republics and on the south by the Gulf of Guinea and Atlantic Ocean (see Figure 1). The land area is 909,890 sqkm with an estimated population of over 200 million people. It is the most populous nation in Africa and contains more than 350 ethno-linguistic groups. The country as at today 
has evolved into a political structure that consists of 36 states and a Federal Capital Territory (Abuja), all constitutionally summarized into six geopolitical zones.
There are also, 774 Local Government Areas in Nigeria (Ademiluyi, 2020).

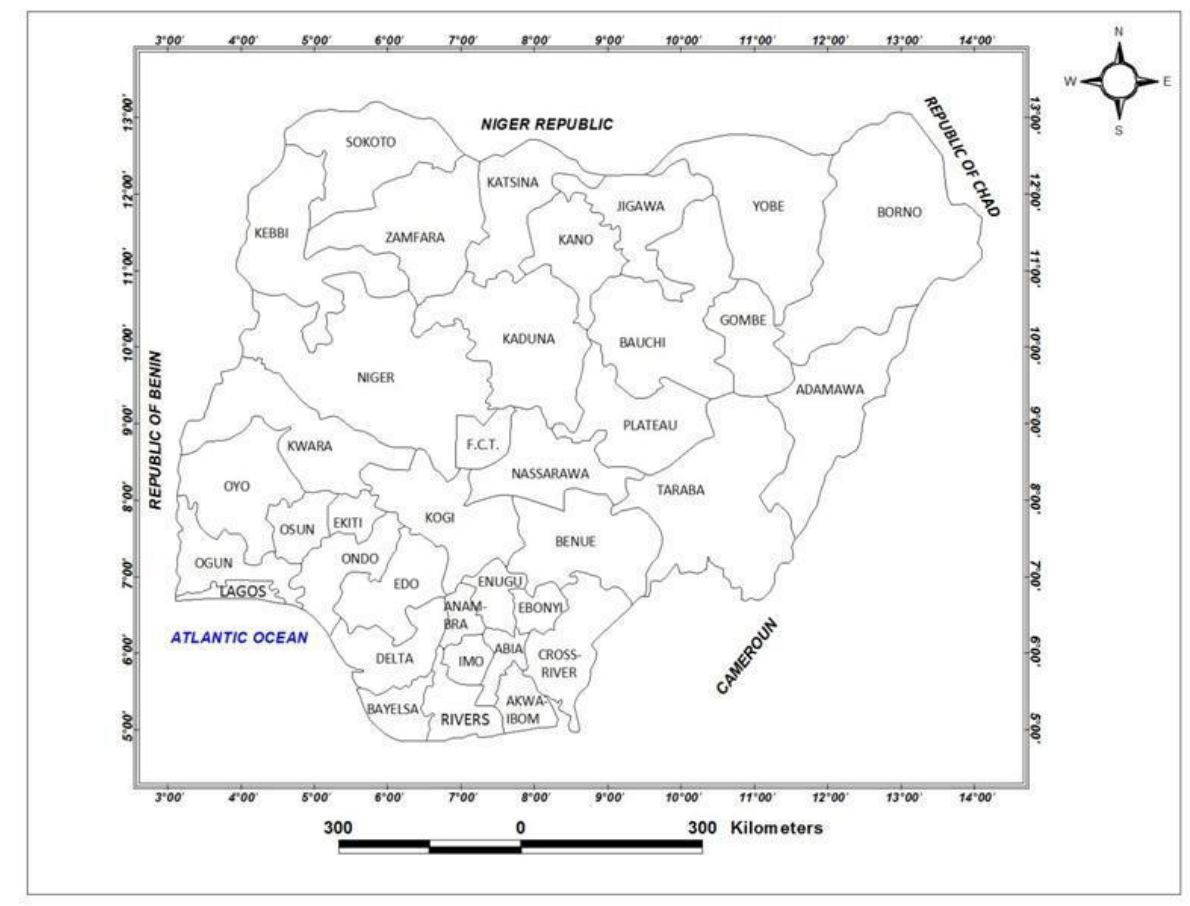

Figure 1: Map of the Study Area ( Nigeria). Source: Oyo State Ministry of Lands, Survey and Urban Planning, Ibadan

\section{Methodology}

\subsection{Data Source and Types}

Data used for this study include: (1) Analogue map of Nigeria sourced from the Oyo State Ministry of Lands, Survey and Urban Planning, Ibadan and (2) situation reports on COVID 19 in Nigeria as at January 3, 2021 by the Nigeria Centre for Disease Control (NCDC). The GIS software used for this study is ArcGIS 10.

\subsection{Data Conversion and Processing}

The health indicators (number of COVID-19 attributable deaths, active, discharged and confirmed cases) across the thirty-six (36) states in Nigeria including the Federal Capital Territory (FCT), Abuja as at January 3,2021 (Table 1) served as the input data for generating the thematic maps to study the spread of the pandemic. The Geographic Information System (GIS) software used in generating the thematic maps is ArcGIS 10.0. The hard copy of the map of Nigeria acquired was scanned into the GIS environment. Geo-referencing was done by the use of tied-points method. The geo-referenced map portrayed information as to where the areas represented on the map fits on the surface of the earth. It was then digitized using on-screen method with the national and state boundaries captured as polygon feature. The health indicators data were restructured in a format (Text Delimited) for implementation in the GIS environment and linked it to the digitized national and state boundaries as their attributes to produce maps (Figures 1, 2, 3\&4) that show the situation of COVID-19 in Nigeria.

\section{Results and Discussions}

The thematic maps generated in this study (Figures 1 to 4) present the spread pattern of COVID-19 Confirmed, Recoveries, Death and Active cases in Nigeria by States including the Federal Capital Territory (FCT), Abuja. The figure shows a high spread in the confirmed cases of COVID-19 across the country with Lagos State recording the highest making the state an epicenter of the pandemic followed by FCT, Abuja (see Figure1). There are also high prevalence of confirmed cases of COVID-19 in the following States; Oyo, Rivers, Kaduna and Plateau, these are followed closely by Katsina, Kano, Gombe, Kwara, Ogun, Ondo, Edo, Delta and Enugu. The high level of spread in confirmed cases of COVID-19 in these states is may be largely due to the following pandemic risk factors; high exposure to international travelers, high urban population and densities plus displacement of people especially in the conflict areas ( ACSS 2020,April 3 ). The number of people that have recovered from the virus infection as at 3rd of January, 2021is also shown graphically (see Figure 2). Lagos State has the highest number of recoveries followed by Kaduna State, Plateau State and FCT, Abuja. The death rate recorded due to the pandemic is high in Lagos State ranging between 118 and 247 cases followed by Edo State and FCT, Abuja ranging from 69 to 117 cases (Figure 3). 


\begin{tabular}{|c|c|c|c|c|}
\hline States & $\begin{array}{c}\text { Confirmed } \\
\text { cases }\end{array}$ & $\begin{array}{c}\text { Total } \\
\text { Active } \\
\text { cases }\end{array}$ & $\begin{array}{c}\text { Discharged } \\
\text { cases }\end{array}$ & $\begin{array}{c}\text { Number } \\
\text { of Deaths }\end{array}$ \\
\hline Lagos & 31321 & 4279 & 26795 & 247 \\
\hline FCT, Abuja & 12083 & 4391 & 7588 & 104 \\
\hline Kano & 2324 & 326 & 1930 & 68 \\
\hline Oyo & 4035 & 581 & 3402 & 52 \\
\hline Rivers & 3572 & 299 & 3209 & 64 \\
\hline Edo & 2902 & 104 & 2681 & 117 \\
\hline Ogun & 2552 & 226 & 2292 & 34 \\
\hline Kaduna & 5447 & 686 & 4708 & 53 \\
\hline Delta & 1888 & 99 & 1737 & 52 \\
\hline Borno & 806 & 32 & 738 & 36 \\
\hline Bauchi & 1020 & 143 & 860 & 17 \\
\hline Gombe & 1338 & 300 & 1001 & 37 \\
\hline Katsina & 1636 & 180 & 1429 & 27 \\
\hline Jigawa & 407 & 28 & 368 & 11 \\
\hline Plateaul & 4997 & 393 & 4560 & 44 \\
\hline Ebonyi & 1107 & 5 & 1072 & 30 \\
\hline Imo & 766 & 31 & 722 & 13 \\
\hline Abia & 1028 & 50 & 968 & 10 \\
\hline Nasarawa & 898 & 560 & 325 & 13 \\
\hline Kwara & 1414 & 289 & 1094 & 31 \\
\hline Bayelsa & 534 & 92 & 421 & 21 \\
\hline Enugu & 1400 & 31 & 1348 & 21 \\
\hline Sokoto & 380 & 92 & 270 & 18 \\
\hline Ondo & 1843 & 39 & 1763 & 41 \\
\hline Zamfara & 112 & 25 & 82 & 5 \\
\hline Kebbi & 173 & 20 & 144 & 9 \\
\hline Anambra & 328 & 35 & 274 & 19 \\
\hline Niger & 417 & 84 & 320 & 13 \\
\hline Akwa Ibom & 437 & 43 & 385 & 9 \\
\hline Osun & 1019 & 30 & 965 & 24 \\
\hline Yobe & 201 & 49 & 144 & 8 \\
\hline Adamawa & 424 & 161 & 238 & 25 \\
\hline Benue & 532 & 52 & 469 & 11 \\
\hline Ekiti & 415 & 14 & 395 & 6 \\
\hline Taraba & 217 & 23 & 187 & 7 \\
\hline Kogi & 5 & 0 & 3 & 2 \\
\hline Cross River & 169 & 0 & 157 & 12 \\
\hline Total & 90,147 & 13,792 & 75,044 & 1,311 \\
\hline
\end{tabular}

Table 1: COVID-19 Situation Report in Nigeria.

Source: Nigeria Centre for Disease Control (NCDC, 2021).

Active cases of COVID-19 infection across the country is still very high as at January 3,2021 with the following States; Lagos, Kaduna, Nasarawa, Oyo, Plateau and FCT, Abuja still potentially at risk of the virus infections ( see Figure 4). The findings of this study shows a rise in the spread of COVID-19 in Nigeria as at January 3,2021 and still on the increase as the country is into the second wave of the virus prevalence (NCDC, 2021).
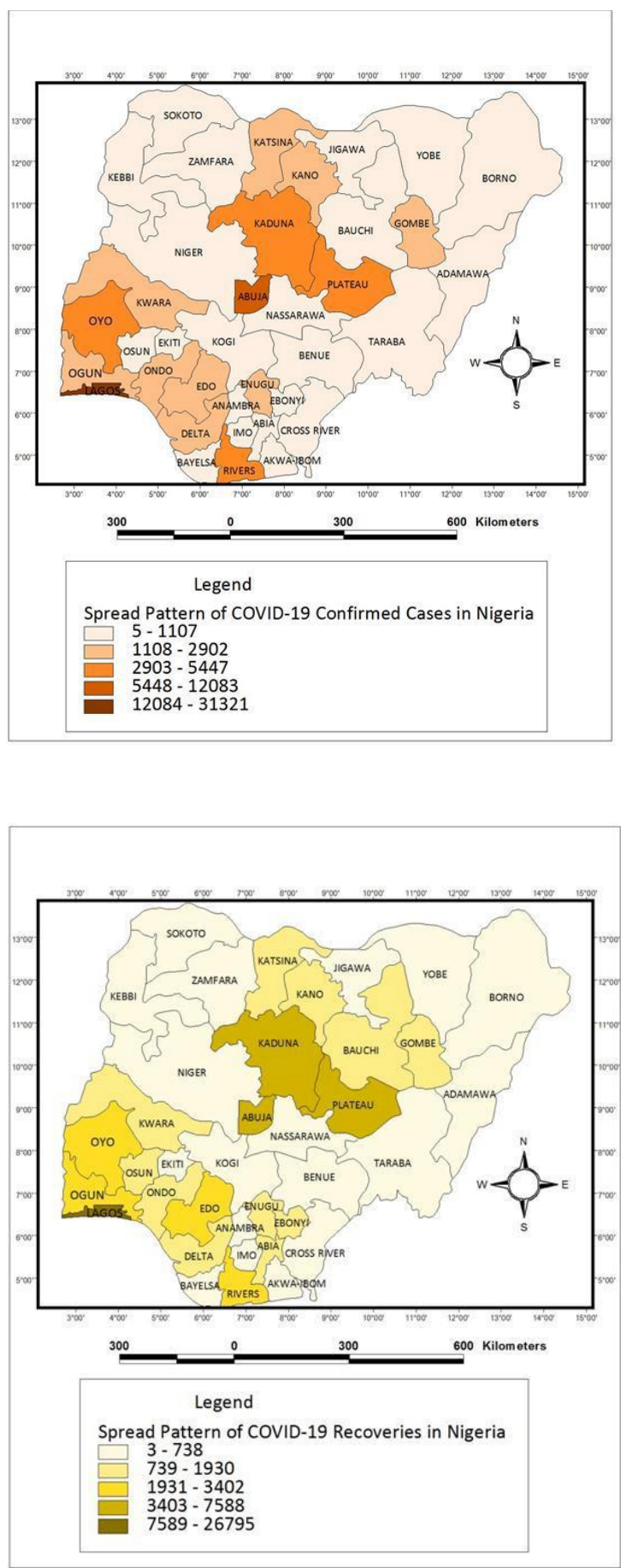

Figure 1\& 2: Spread Pattern of COVID-19 Confirmed Cases and Recoveries in Nigeria 


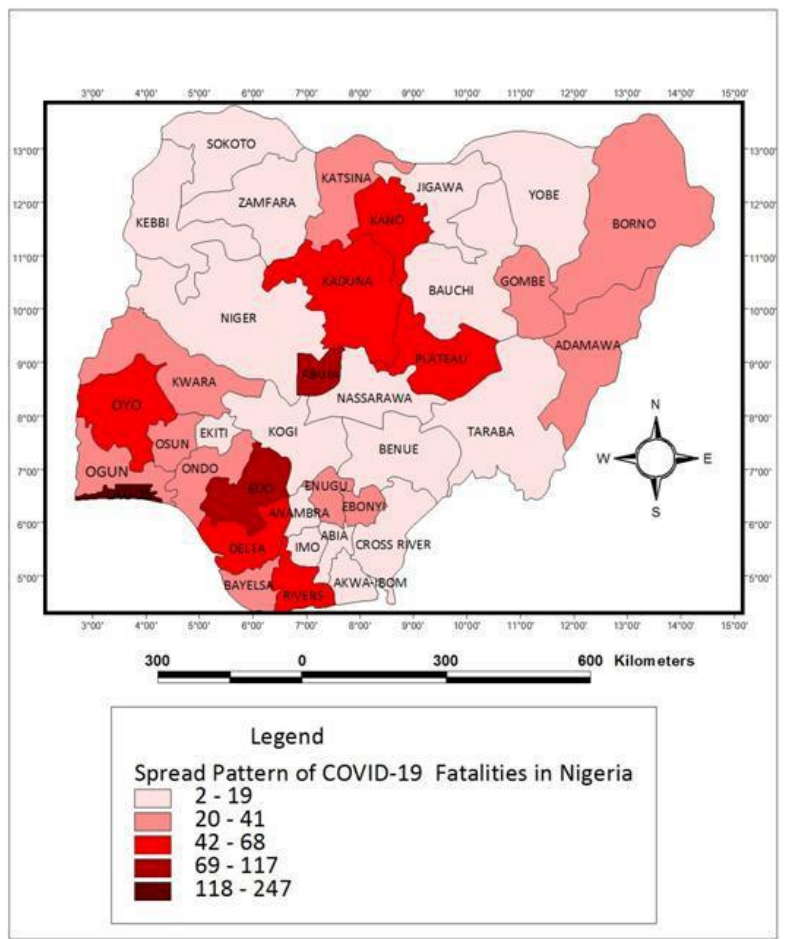

Figure 3: Spread Pattern of COVID-19 Fatalities in Nigeria

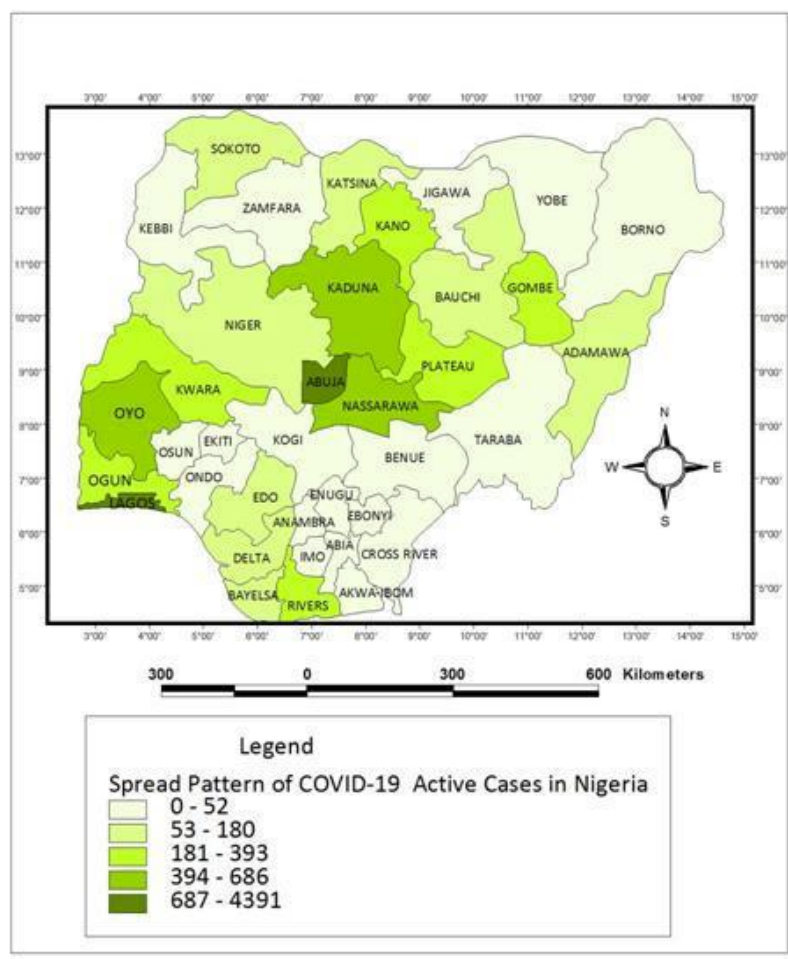

Figure 4: Spread Pattern of COVID-19 Active Cases in Nigeria

\subsection{Implications of Study}

Since human to human contact is still the major factor for the spread of this deadly virus, thematic maps like the ones generated and presented visually in this study can be employed by all relevant stakeholders for quick decision making concerning its spread such as restrictions of movements from and into hotspot states (intra and interstate movement), whether to have total or partial lockdown, in having effective responses in terms of medical facilities and palliative measures that will help in reducing the effects. These maps put together can also serve the purpose of early warning now and in the future. These maps can further be used to control community and neighborhood spread in Nigeria and globally. Generally, geo-visualization analysis of health events through the use of thematic mapping techniques has the capacities of storing, analyzing and displaying such in a simple graphic form for quick understanding and interpretation.

\section{Conclusion and Recommendations}

This study explored the techniques of Thematic mapping to visualize the spread of the novel corona virus disease (COVID-19) across the 36 states in Nigeria including the Federal Capital Territory (FCT), Abuja. It equally presented how thematic maps could be used to explain public health phenomenon for quick decision and intervention. Lagos, Kano, Kaduna, Oyo, Plateau and Rivers states together with FCT, Abuja were found to be the most hardly hit areas in Nigeria by the rampaging virus (estimated in terms of confirmed cases and the number of deaths recorded) with the South-West geopolitical zone having the highest number of both confirmed and active cases. It also established how maps like the ones generated in this study can be used to checkmate the spread of diseases across the space. The study concludes by recommending a proactive involvement of thematic mapping among other numerous methods for explaining public health phenomena by all relevant stakeholders for quick planning, preparedness and responses.

\section{References}

Ademiluyi, I.A. (2020). Human Geography and the Search for a New Nigeria. 95th Inaugural Lecture. Olabisi Onabanjo University, Ago- Iwoye, Ogun State.

ACSS (2020, April 3). Mapping Risk Factors for the Spread of COVID-19 in Africa. Infographic. Africa Center for Strategic Studies (updated on May 13, 2020).

Bartz Petchenik, B. (April 1979). "From Place to Space: The Psychological Achievement of Thematic Mapping". Cartography and Geographic Information Science. 6 (1): 5-12. doi:10.1559/152304079784022763.

Dent, B. D., Torguson, J. S and Hodler, T. W. (2009). Cartography: Thematic Map Design. McGraw-Hill. p. 7. ISBN 978-0-07-294382-5.

Keates, J. S. (1973). Cartographic design and production. Longman. p. 59.

Robinson, A. H. (1982). Early Thematic Mapping in the History of Cartography. University of Chicago Press.

Kraak, M. J and Ormeling, F (2003). Cartography: Visualization of spatial data (2nd ed.). Prentice Hall. ISBN 978-0-13-088890-7. p. 129. 